\title{
$\mathrm{Zr}$ 기지 비정질 합금 스크랩의 비정질 형성능 및 기계적 성질에 미치는 재용해 횟수와 탄소 함량의 영향
}

이병철 - 김성규* - 박봉규* - 박흥일* - 박화순 *广

(주퍼포먼스머티리얼코리아, *부경대학교 신소재시스템공학과

\section{The Effect of Remelting Cycles and Its Carbon Content on the Glass Forming Ability and Mechanical Properties of the Zr-based Amorphous Alloy Return Scrap}

\author{
Byung-Chul Lee, Sung-Gyoo Kim*, Bong-Gyu Park*, Heung-Il Park* and Hwa-Soon Park*广 \\ Performance Material Korea Co. Ltd., Eoyeon Hansan Industrial Complex, Cheongbuk-myeon Pyeongtaek-si Gyeonggi-do 451-833, Korea \\ *Pukyung National University, Department of Materials System Engineering, San 100 Yongdang-dong Nam-gu, Busan 608-737, Korea
}

\begin{abstract}
A commercially used Zr-based amorphous alloy was recycled and the effects of introducing carbon during recycling on the glass forming ability and mechanical properties of the alloy were investigated. The initial carbon content used in this study was $229 \mathrm{ppm}$. The carbon content was gradually increased as the number of recycling iterations was increased and after the $4^{\text {th }}$ recycling it rapidly increased. As return scrap was recycled, polygonal particles precipitated, and they were identified as $\mathrm{ZrC}$. The amount of the precipitates also increased with recycling. $\mathrm{Tg}$, $\mathrm{Tx}$ and $\Delta \mathrm{T}$ of the base alloy were $615 \mathrm{~K}, 696 \mathrm{~K}$ and $81 \mathrm{Kr}$ respectively and they changed to $634 \mathrm{~K}, 706 \mathrm{~K}$ and $72 \mathrm{~K}$ after the $10^{\text {th }}$ recycling. The decrease of the $\Delta \mathrm{T}$ value indicates deterioration of the glass forming ability. Hardness was not changed during three iterations of recycling but after the $4^{\text {th }}$ recycling it significantly increased. This is ascribed to an increase of amount of the hard particles, namely $\mathrm{ZrC}$.
\end{abstract}

Key words : Zr-based amorphous alloy, Recycling, Carbon content, Mechanical properties

\section{1. 서 론}

1960년 급속응고법에 의하여 $\mathrm{Au}-\mathrm{Si}$ 계 비정질 합금이 발견된 이래, 지금까지 수많은 연구에 의해 $\mathrm{Zr}, \mathrm{Ti}, \mathrm{Mg}$ 및 $\mathrm{Ti}$ 계 등 의 합금계에서 비정질 벌크 합금이 개발되었고, 최근에는 $\mathrm{Fe}$ 계에서도 비정질 벌크 합금이 개발되기에 이르렀다[1-7].

특히 1990년대 CALTECH의 Johnson 등에 의해 개발된 $\mathrm{Zr}-\mathrm{Ti}-\mathrm{Cu}-\mathrm{Ni}-\mathrm{Be}$ 계 비정질 벌크 합금은 지금까지 발견된 일반 적인 비정질 합금의 임계냉각속도보다 느린 $1 \mathrm{~K} / \mathrm{s}$ 의 냉각속도 에서도 비정질 벌크 합금의 제조가 가능하기 때문에 휴대폰 부품, 의료기 부품 및 게임기 케이스 등 산업용으로 활용할
수 있게 되었다.

그러나 현대산업에서는 가격이 싸고, 품질이 우수한 제품이 요구되어지고 있다. 이러한 조건을 만족시키기 위해서는 원자 재의 가격을 낮추고, 회수반재(return scrap)를 재활용하는 것 이 필요하다. 먼저 원자재의 가격을 낮추려면 순도가 낮아지고 불순물이 포함될 수밖에 없다. 이 불순물은 비정질 형성능을 나쁘게 하는 요인으로 작용하게 된다. 또한, 고순도의 원재료 를 사용하여 제품을 만들고, 남은 스크랩을 회수하여 재활용하 는 것은 제품의 원가를 절감할 수 있는 중요한 공정이지만, 재용해 횟수가 증가함에 따라 회수반재 중의 탄소 함량이 증 가하므로 제품의 품질에도 큰 영향을 미칠 수 있다.

Received: Mar. 12, 2014 ; Revised: May. 19, 2014 ; Accepted: Jun. 9, 2014 Journal of Korea Foundry Society "Corresponding author: Hwa-Soon Park (Pukyung National Univ.) 2014. Vol. 34 No 3 pp. 094 099 Tel: +82-51-629-6375, Fax: +82-51-629-6373 E-mail: parkhs@pknu.ac.kr

http://dx.doi.org/10.7777/jkfs.2014.34.3.094 ISSN 1598-706X

(c) Korea Foundry Society, All rights reserved.

This is an Open-Access article distributed under the terms of the Creative Commons Attribution Non-Commercial License (http://creativecommons.org/licenses/by-nc/3.0) which permits unrestricted non-commercial use, distribution, and reproduction in any medium, provided the original work is properly cited. 
본 연구에 사용된 $\mathrm{Zr}$ 계 합금에는 독성이 강한 $\mathrm{Be}$ 이 포함되 어 있으므로 실제 생산 공정에서는 아크용해를 할 수 없고, 흑연도가니를 사용하여 고주파 유도 용해로 합금을 제조하고 있기 때문에 합금 중에 탄소가 혼입될 수밖에 없으며, 이것이 회수반재의 재활용을 어렵게 하여 제품의 가격 경쟁력에 나쁜 영향을 끼치고 있다.

따라서 본 연구에서는 고순도의 원재료를 사용하여 고주파 유도 용해로 $\mathrm{Zr}$ 기 비정질 벌크 합금을 제조하였으며, 합금 제 조 후 남은 스크랩을 재용해한 합금 중의 탄소 함량을 확인하 며, X-선 회절, DSC, DTA 및 미소경도시험에 의하여 재용해 횟수에 따른 비정질 형성능과 기계적 특성의 변화 등을 조사 하였다.

\section{2. 실험 방법}

본 연구에서 사용한 $\mathrm{Zr}, \mathrm{Ti}, \mathrm{Ni}$ 및 $\mathrm{Cu}$ 는 순도 $99.9 \%$ 에서 99.99\%의 원소들을, 또한 $\mathrm{Be}$ 은 $\mathrm{NiCuBe}$ 모합금을 제조하여 각각 목표하는 성분조성에 알맞게 평량하여 진공 유도 용해로 $\left(1.3 \times 10^{-1} \mathrm{~Pa}\right)$ 에서 고순도 $\mathrm{Ar}$ 가스 $(99.99 \%)$ 를 주입하여 용해 하였다. 목표조성의 용탕을 waffle type의 금형에 주입하여 비 정질 합금 시편을 제조하였다.

Table 1은 본 연구에 사용된 비정질 모합금 시편의 화학조 성을 나타내며, Fig. 1은 waffle type의 금형의 형상 치수와 실제 금형의 사진을 보여 준다.

모합금 시편을 채취하고 남은 비정질 합금 스크랩을 평량하 고 초음파 세척하여 모합금 용해와 동일한 용해조건에서 재용 해하고 수직 진공 다이캐스팅으로 주조공정 시편을 제조하였다. 각각의 시편은 재용해 횟수를 달리하여 제조하였으며, Fig. 2 는 재활용 합금의 시편제조 공정을 보여 준다. Fig. 3는 진공 다이케스팅의 외관과 진공 다이케스팅으로 제조된 시편의 형상 을 보여 준다.

Table 1. Chemical compositions of prepared specimen.

\begin{tabular}{cccccc}
\hline Element & $\mathrm{Zr}$ & $\mathrm{Ti}$ & $\mathrm{Cu}$ & $\mathrm{Ni}$ & $\mathrm{Be}$ \\
\hline Composition & 62.60 & 11.01 & 13.23 & 9.78 & 3.38 \\
\hline
\end{tabular}
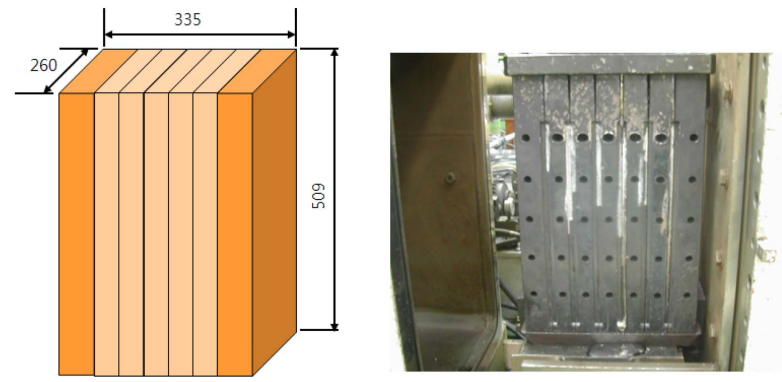

Fig. 1. Configuration and photograph of the waffle type die.

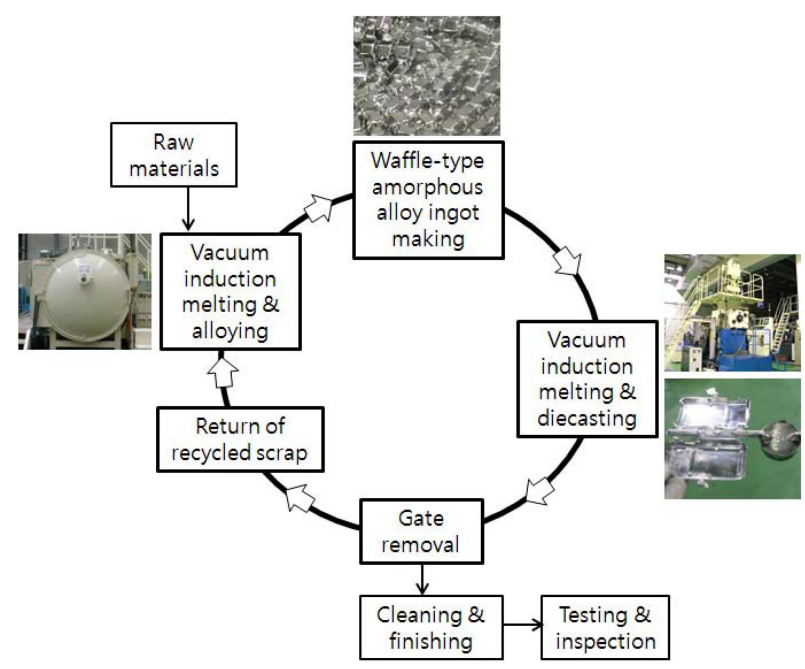

Fig. 2. Schematic illustration of specimen preparation process.
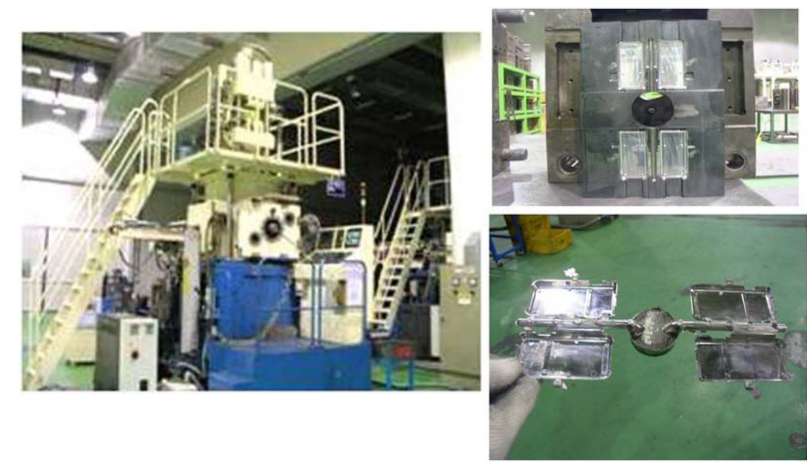

Fig. 3. Photographs of vacuum die-casting machine and prepared specimen.

진공유도용해로에서 제조된 합금과 진공 다이캐스팅으로 제 조된 시편을 각각 $0.1 \mathrm{~g}$ 씩 평량한 후 재용해 횟수에 따른 탄 소함유량의 변화를 탄소분석기로 분석하였다.

재용해 횟수에 따른 합금의 조직을 광학현미경으로 관찰하였 으며, 광학현미경에서 관찰된 석출물의 크기와 형상은 주사전자 현미경으로 관찰하였고, 석출물의 성분은 $\mathrm{EDX}$ 로 분석하였다.

재용해 시편에서 관찰된 석출물의 상분석은 미세 $\mathrm{X}$-선 회절 분석기를 이용하여 조사하였다. 본 실험의 미세 X-선 회절 분 석은 $\mathrm{Cu} K_{\alpha}$ 선을 사용하였고, 전압과 전류는 각각 $40 \mathrm{kV}$ 및 $30 \mathrm{~mA}$ 의 조건으로 분석하였다. 미세 X-선 회절 스펙트럼은 연속 주사의 방법으로 $20^{\circ} \sim 80^{\circ}$ 의 주사 범위에서 $5 \% \mathrm{~min}$ 의 속 도로 분석하였다.

경도는 미소경도기를 이용하여 $500 \mathrm{gf}$ 의 하중으로 일정 거리 를 유지하며 5 회 측정하여 평균값을 나타내었다.

\section{3. 실험 결과 및 고찰}

재용해 비정질 벌크 합금의 탄소분석은 모합금 용해공정과 


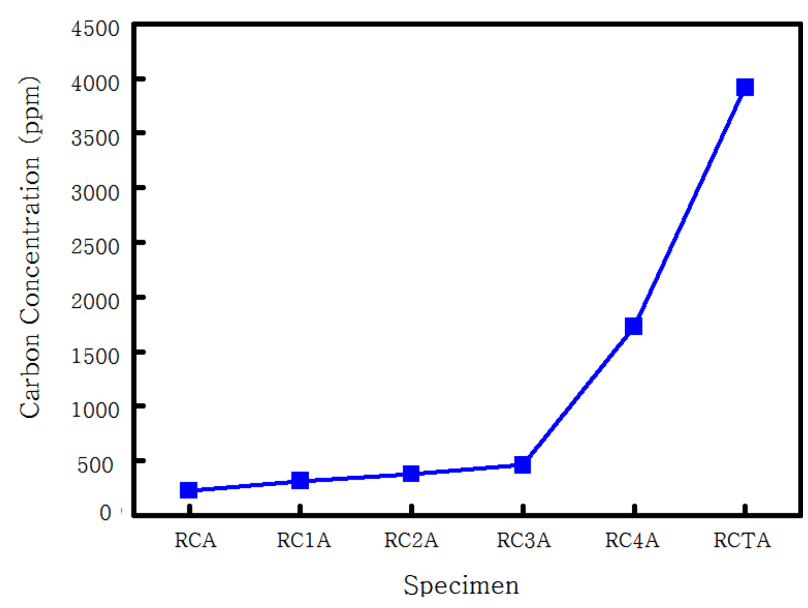

Fig. 4. Carbon concentration of recycled materials in alloy process.

주조공정에서 제조된 각각의 시편으로 분석하였다. Fig. 4는 모합금 용해공정에서 제조된 시편의 탄소 분석 결과를 나타낸 다. 원재료를 사용한 합금의 탄소함량은 $229 \mathrm{ppm}, 1$ 회 재용해 한 합금인 $\mathrm{RC1A}$ 는 $320 \mathrm{ppm}, 2$ 회 재용해한 합금인 $\mathrm{RC} 2 \mathrm{~A}$ 는 $380 \mathrm{ppm}$, 3회 재용해한 합금인 $\mathrm{RC} 3 \mathrm{~A}$ 는 $461 \mathrm{ppm}$ 그리고 4 회 재용해한 합금인 RC4A는 $1,730 \mathrm{ppm}$ 이었다. 마지막 합금인 $\mathrm{RCTA}$ 는 재용해 횟수가 10 회인 합금으로 탄소 함량은 3,917 $\mathrm{ppm}$ 이었다. 합금 공정에서 재용해 횟수가 증가할수록 점진적 으로 탄소의 함량이 증가하고 있으며, 4 회 재용해한 합금은 3

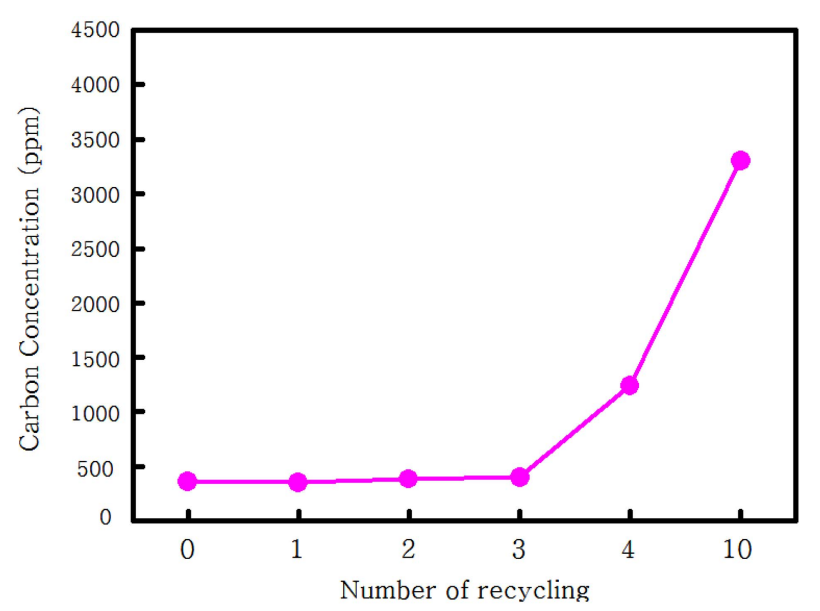

Fig. 5. Carbon concentration of recycled materials in casting process.

회 재용해한 합금에 비해 급격하게 증가함을 알 수 있다.

Fig. 5는 주조공정으로 제조한 합금의 탄소분석 결과를 나타 낸다. 원재료를 사용한 합금의 탄소 함량은 $351 \mathrm{ppm}, \mathrm{RC} 1 \mathrm{~A}$ 는 $360 \mathrm{ppm}, \mathrm{RC} 2 \mathrm{~A}$ 는 $384 \mathrm{ppm}, \mathrm{RC} 3 \mathrm{~A}$ 는 $397 \mathrm{ppm}, \mathrm{RC} 4 \mathrm{~A}$ 는 $1,239 \mathrm{ppm}$ 그리고 $\mathrm{RCTA}$ 는 $3,302 \mathrm{ppm}$ 이었다. 주조공정에서의 탄소 함량도 재용해 횟수가 증가할수록 점차 증가함을 알 수 있으며, 4회 재용해한 합금은 3회 재용해한 합금에 비해 급격 하게 증가하는 것도 모합금 용해공정과 동일한 경향을 나타내 었다.
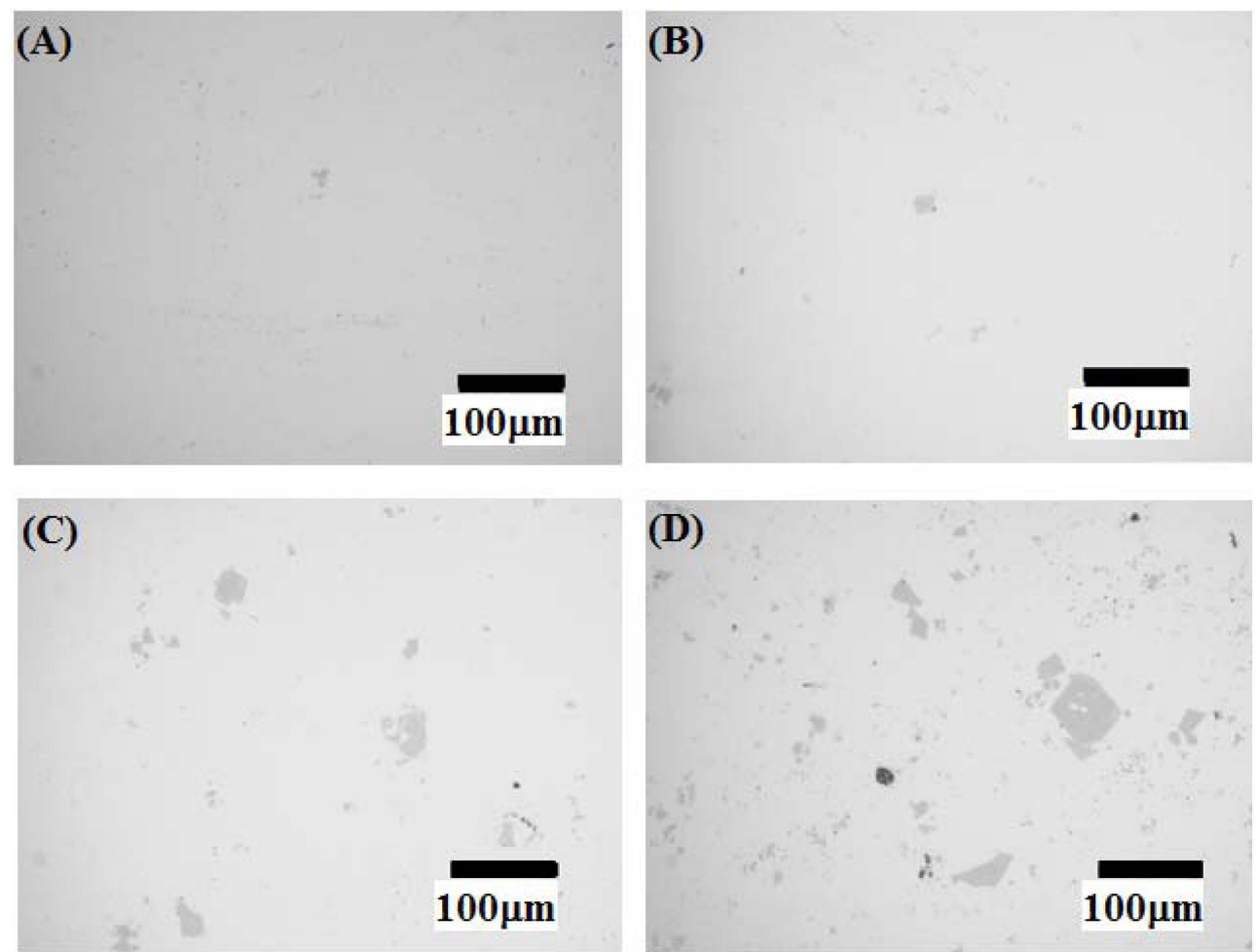

Fig. 6. Optical micrographs of recycled amorphous alloys with various carbon content. (A) 320ppm (B) 461ppm (C) 1,730ppm (D) 3,917ppm. 
탄소 함량의 변화는 주조공정보다 합금공정 쪽이 크며, 그 이유는 합금공정은 재료의 완전한 용해와 균일한 용해를 위하 여 작업 온도가 주조공정보다 높으므로 $\mathrm{Zr}$ 과 반응성이 좋은 탄소가 쉽게 혼입되기 때문이라고 생각된다.

Fig. 6는 재용해한 합금의 미세 조직을 관찰한 광학현미경 사진이다. 백색의 비정질 기지에 다각형의 석출물이 관찰되고 있다. Fig. 6(a)는 1회 재용해한 합금으로 석출물의 크기가 작 고 양도 적었다. Fig. 6(b)는 3회 재용해한 합금으로 석출물 의 크기는 작지만, 양은 1 회 재용해한 합금보다 증가하였다. Fig. 6(c)는 4회 재용해한 합금으로 석출물의 크기와 양이 (a), (b)에 비해 많이 증가되어 있음을 알 수 있다. Fig. 6(d) 는 10 회 재용해한 합금으로 크기가 상당히 큰 석출물과 크기 가 작은 석출물이 동시에 관찰되고 있다.

재용해 횟수가 증가함에 따른 석출물의 성분을 주사전자현미 경(SEM)으로 분석하였다. Fig. 7은 10회 재용해한 합금의 $\mathrm{SEM}-\mathrm{EDX}$ 사진으로 석출물은 $\mathrm{Zr}$ 과 $\mathrm{C}$ 의 화합물로 밝혀졌으며, 이 석출물의 micro XRD 분석결과를 Fig. 8에 나타낸다. Micro XRD의 X-선 빔의 크기는 $0.5 \mathrm{~mm} \times 0.5 \mathrm{~mm}$ 으로 기지 는 비정질 단상임을 알 수 있으며, 석출물은 비정질의 기지와 석출물이 동시에 조사되어 비정질 기지에 $\mathrm{ZrC}$ 가 공존하는 것 으로 분석되었다.

$\mathrm{Zr}$ 기지 합금의 주원소인 $\mathrm{Zr}$ 과 친화력이 상당히 좋은 탄소는 용해 작업에 사용되는 흑연도가니와 주조 작업에 사용되는 흑
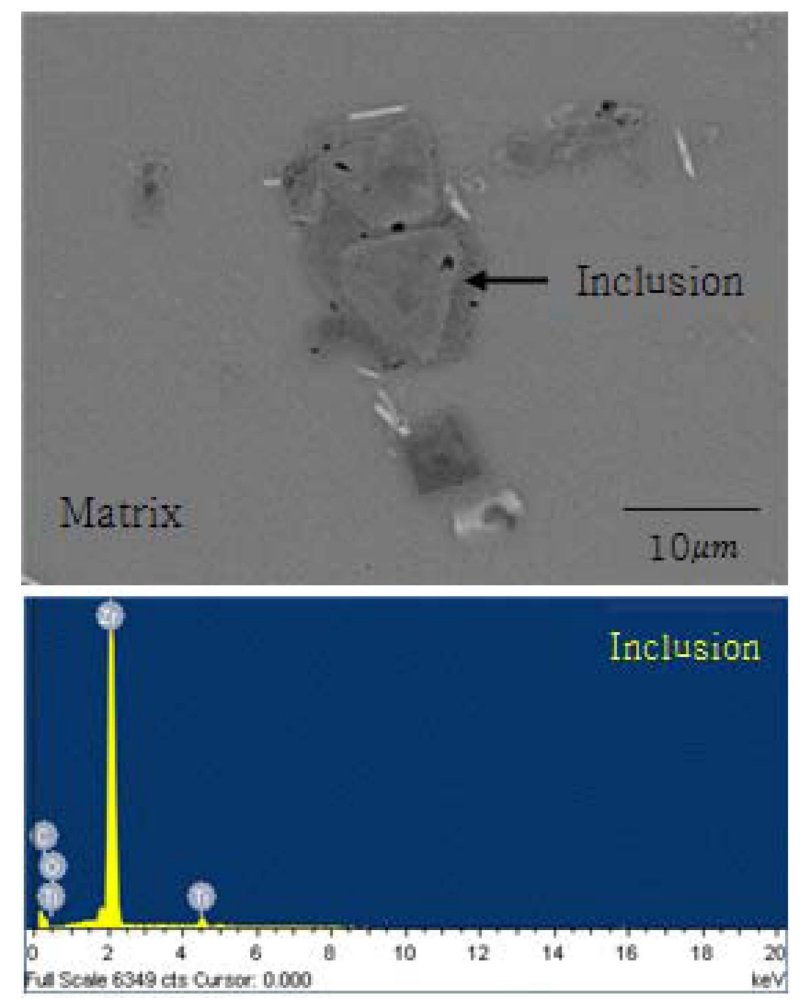

Fig. 7. SEM-EDX result on the polygon inclusions in 3,917ppm carbon alloyed amorphous specimen.
연도가니에서 혼입된 것으로 판단된다.

Fig. 9은 재용해 횟수의 증가에 따른 $\mathrm{DSC}$ 곡선을 나타낸다. 원재료를 사용한 합금의 $\mathrm{Tg}, \mathrm{Tx}$ 및 $\Delta \mathrm{T}(=\mathrm{Tx}-\mathrm{Tg})$ 는 각각 $615 \mathrm{~K}, 696 \mathrm{~K}$ 및 $81 \mathrm{~K}, 3$ 회 재용해한 합금은 $615 \mathrm{~K}, 697 \mathrm{~K}$ 및 $82 \mathrm{~K}$ 로 거의 변화가 없었지만, 두 번째 발열 피크의 높이 가 낮아져 일정량의 석출물이 석출되었음을 유추할 수 있다. 재용해 횟수가 4회 및 10 회로 증가함에 따라 $\mathrm{Tg}$ 는 각각 $622 \mathrm{~K}$ 및 $634 \mathrm{~K}$ 로 상승하였고, $\mathrm{Tx}$ 는 각각 $699 \mathrm{~K}$ 및 $706 \mathrm{~K}$ 로 상승하였지만, $\Delta \mathrm{T}$ 는 $77 \mathrm{~K}$ 및 $72 \mathrm{~K}$ 로 감소하고 있다. 반면 에 두 번째 발열 피크의 높이는 점차 낮아져, 재용해 횟수가 증가함에 따라 석출물의 양이 증가하고 있다고 판단된다.

Fig. 10 은 재용해 횟수의 증가에 따른 DTA곡선을 나타낸다. 재용해 횟수가 $0,3,4$ 및 10 회로 증가함에 따라 합금의 융점 $(\mathrm{Tm})$ 은 $967 \mathrm{~K}, 975 \mathrm{~K}, 980 \mathrm{~K}$ 및 $991 \mathrm{~K}$ 로 점차 상승하고 있 으며, Fig. 6 및 Fig. 7의 결과를 종합하여 Table 2에 나타낸

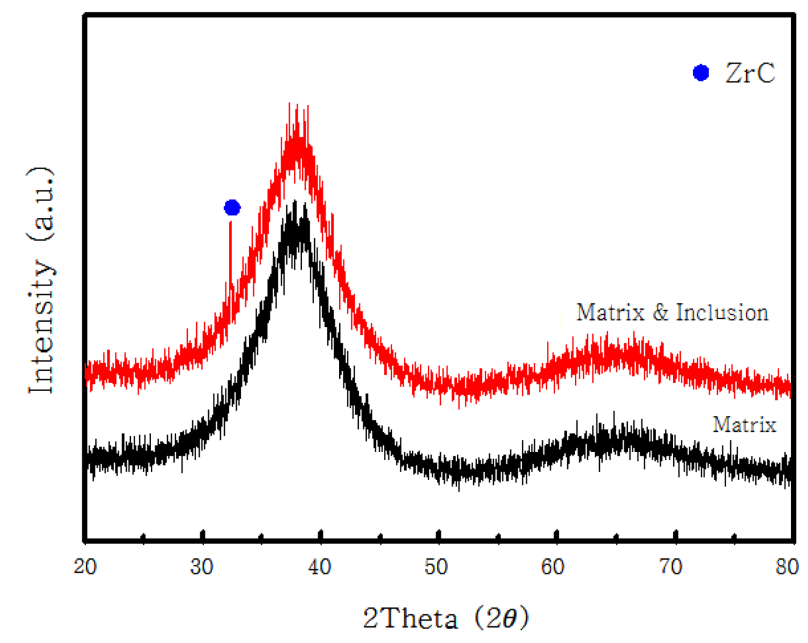

Fig. 8. Micro-XRD patterns of precipitate particles.

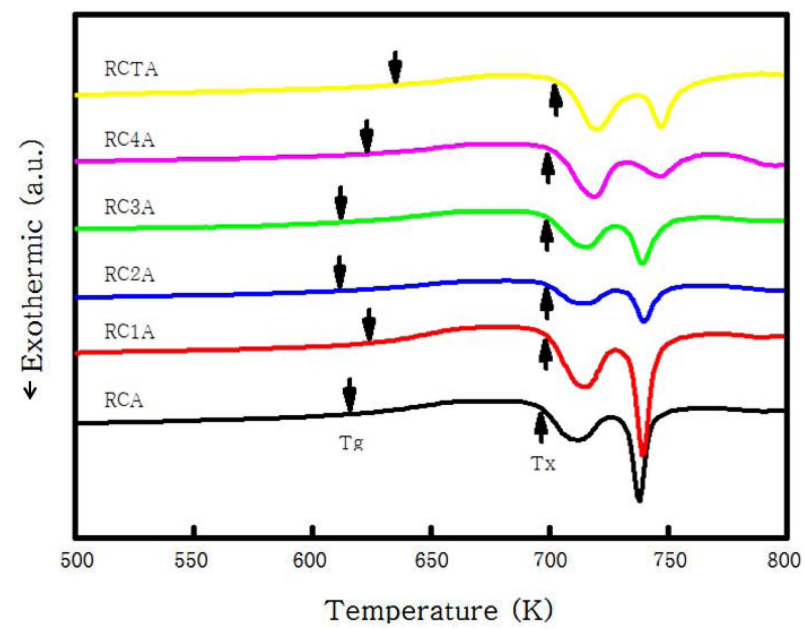

Fig. 9. DSC curves of remelted amorphous alloy specimen. 


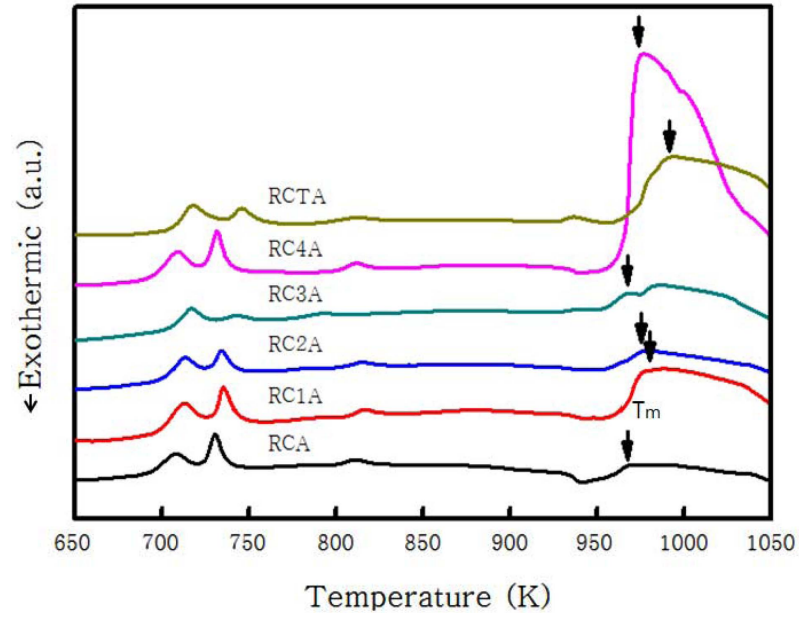

Fig. 10. DTA curves of remelted amorphous alloy specimen.

Table 2. Tg, $\mathrm{Tx}, \mathrm{Tm}$ and $\Delta \mathrm{T}$, Trg of recycled amorphous specimens.

\begin{tabular}{ccccccc}
\hline & RCA & RC1A & RC2A & RC3A & RC4A & RCTA \\
\hline Tg & 615 & 623 & 612 & 613 & 622 & 634 \\
$\mathrm{Tx}$ & 696 & 698 & 698 & 698 & 699 & 706 \\
$\Delta \mathrm{T}$ & 81 & 75 & 86 & 85 & 77 & 72 \\
$\mathrm{Tm}$ & 967 & 980 & 977 & 975 & 980 & 991 \\
$\mathrm{Trg}$ & 0.64 & 0.64 & 0.63 & 0.63 & 0.63 & 0.64 \\
\hline
\end{tabular}

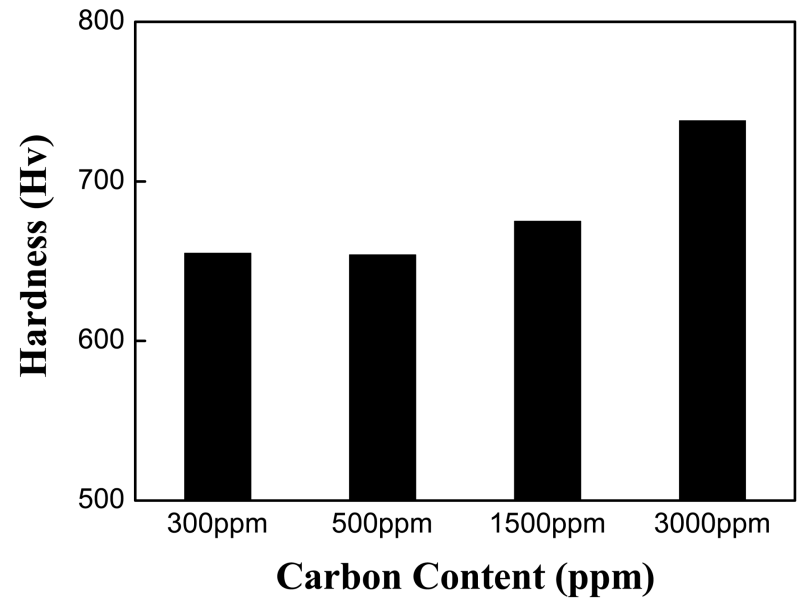

Fig. 11. Relation between micro-vickers hardness and carbon content of remelted amorphous alloy specimen.

다. 이것으로부터 재용해 횟수가 증가함에 따라 비정질 형성능 이 급격하게 떨어지고 있음을 알 수 있다.

Fig. 11은 재용해 횟수에 따른 경도의 변화를 측정한 결과를 나타낸다. 1회 재용해한 합금은 $\mathrm{Hv} 655,3$ 회 재용해한 합금 은 $\mathrm{Hv} 654,4$ 회 재용해한 합금은 $\mathrm{Hv} 675$ 그리고 10회 한 합금은 $\mathrm{Hv}$ 738의 경도값을 각각 나타낸다. 다각형 석출물의 경도는 $\mathrm{Hv} 851$ 로 기지보다 상당히 높은 값을 나타내었다. 재
용해 횟수가 증가함에 따라 석출물의 양이 증가하기 때문에 경도가 상승하고 있다고 판단된다.

\section{4. 결 론}

고순도의 원재료로 합금한 $\mathrm{Zr}$ 기 비정질 벌크 합금의 재용해 횟수에 따른 탄소 함유량 변화가 비정질 형성능 및 기계적 성 질에 미치는 영향을 조사한 결과, 다음과 같은 결론을 얻었다.

1) 원재료를 사용한 합금의 탄소 함량은 $229 \mathrm{ppm}, 1$ 회 재용 해한 합금은 $320 \mathrm{ppm}, 3$ 회 재용해한 합금은 $461 \mathrm{ppm}, 4$ 회 재 용해한 합금은 $1,730 \mathrm{ppm}$ 그리고 10 회 재용해한 합금은 3,917 $\mathrm{ppm}$ 으로, 재용해 횟수가 증가할수록 점진적으로 탄소함량이 증 가하고 있으며, 특히 4회 재용해한 합금은 3회 재용해한 합금 에 비해 급격하게 증가하였다.

2) 회수반재를 재용해함에 따라 비정질 기지에 다각형의 석 출물이 석출되었고, 재용해 횟수가 증가할수록 $\mathrm{ZrC}$ 의 생성량 과 크기가 증가하였다. 10 회까지 증가함에 따라 석출물의 크 기와 양이 증가하였으며, 이 석출물은 $\mathrm{ZrC}$ 임이 밝혀졌다.

3) 원재료를 사용한 합금의 $\mathrm{Tg}, \mathrm{Tx}$ 및 $\Delta \mathrm{T}$ 는 각각 $615 \mathrm{~K}$, $696 \mathrm{~K}$ 및 $81 \mathrm{~K}$ 이었고, 재용해 횟수가 10 회로 증가함에 따라 $\mathrm{Tg}$ 와 $\mathrm{Tx}$ 는 각각 $634 \mathrm{~K}$ 와 $706 \mathrm{~K}$ 로 상승하였지만, $\Delta \mathrm{T}$ 는 $72 \mathrm{~K}$ 로 감소하여 비정질 형성능이 떨어짐을 알 수 있었다.

4) 회수반재의 재용해 횟수가 증가함에 따른 미소경도의 변 화는 3회까지는 Hv 655 정도로 거의 일정하였지만, 4회에서 는 $\mathrm{Hv} 675,10$ 회에서는 $\mathrm{Hv}$ 738로 크게 상승하였다. 이는 $\mathrm{Hv} 851$ 의 고경도 $\mathrm{ZrC}$ 의 석출양이 증가하였기 때문이다.

\section{감사의 글}

이 논문은 부경대학교 자율창의학술연구비(2013년)에 의하여 연구되었음.

\section{참고문헌}

[1] Klement W, Willen R. H and Duwez P, Nature, "Noncrystalline Structure in Solidified Gold-Silicon Alloys", 187 (1960) 869-870.

[2] Chen H. S, Rep. Pro. Phys., "Glassy Metals", 43 (1980) 353432.

[3] Masumoto T, "Materials Science of Amorphous Metal", (1982) Ohmu Pub., Tokyo.

[4] Luborsky F. E, "Amorphous Metallic Alloy”, (1983) Butterworths, London.

[5] Liebermann H. H, "Rapid Solidified Alloys", (1983) Marcel Dekker Inc., New York.

[6] Inoue A, Zhang T and Masumoto T, Mater. Trans., JIM, “AlLa-Ni Amorphous Alloys with a Wide Supercooled Liquid Region”, 30 (1989) 965-972.

[7] Inoue $A$, Yamaguchi $H$, Zhang $T$ and Masumoto $T$, Mater. Trans., JIM, "Al-La-Cu Amorphous Alloys with a Wide 
Supercooled Liquid Region”, 31 (1990) 104-109.

[8] Inoue A, Zhang T and Masumoto T, Mater. Trans., JIM, "ZrAl-Ni Amorphous Alloys with High Glass Transition Temperature and Significant Supercooled Liquid Region", 31
(1990) 177-183.

[9] Inoue A, Nishiyama N, Amiya K, Zhang T and Masumoto T, Mater. Lett., "Ti-based amorphous alloys with a wide supercooled liquid region”, 19 (1994) 131-135. 